\title{
Perfil de Sensibilidade de Staphylococcus spp. Isolados de Alimentos a Antibióticos de Uso Farmacêutico
}

\begin{abstract}
Maria Gilnara Lima Bandeira (IV), Anakláudia Sombra Santos (II), Maria Rociene Abrantes (III), Germana Guimarães Rebouças (III), Monique Ellen Torres da Silva (IV), Weslley de Souza Paiva (III), Monique de Oliveira Maia (IV), Lidiana Souza Correia Lima (IV), Jean Berg Alves da Silva (III), Marlene Nunes Damaceno (IV)
\end{abstract}

(III) UFERSA - Universidade Federal Rural do Semi Árido (Av. Francisco mota, Mossoró - RN), (IV) IFCE - Instituto Federal do Ceará (Rua Estevão Remígio, 1145 - Centro - Limoeiro do Norte - CE)

\section{Resumo}

O desenvolvimento de antimicrobianos nas últimas décadas levou ao surgimento de diversas drogas com espectro de ação cada vez mais amplo. A exposição a essas substâncias desencadeou resistência bacteriana, limitando as opções terapêuticas dos processos infecciosos. O uso indiscriminado e irresponsável de antibióticos, humano ou veterinário, tem favorecido a pressão seletiva e predominância de espécies bacterianas cada vez mais resistentes. Objetivou-se com este trabalho avaliar o perfil de sensibilidade de Staphylococcus spp. provenientes de alimentos à antibióticos de uso farmacêutico. Foram isolados Staphylococcus spp. de 23 amostras de alimentos diversos (09 amostras de leite, 09 de camarão, 03 de gema de ovo e 02 de bebida láctea sabor morango). As bactérias crescidas em ágar Baird-Parker foram transferidas para caldo $\mathrm{BHI}$ e incubadas a $36^{\circ} \mathrm{C}$ por 48 horas. Após o crescimento, foi realizado o teste antimicrobiano pela técnica de difusão em disco, em Agar Mueller-Hinton, com os seguintes antibióticos: Oxacilina, Gentamicina, Penicilina G, Amicacina, Cefalexina e Ampicilina. O procedimento de leitura foi realizado medindo os halos de inibição formados ao redor dos discos, medidos com paquímetro após $24 \mathrm{~h}$ de incubação a $37^{\circ} \mathrm{C}$. Foi observada

\footnotetext{
Referência:

Maria Gilnara Lima Bandeira, Anakláudia Sombra Santos, Maria Rociene Abrantes, Germana Guimarães Rebouças, Monique Ellen Torres da Silva, Weslley de Souza Paiva, Monique de Oliveira Maia, Lidiana Souza Correia Lima (I.Perfil de Sensibilidade de Staphylococcus spp. Isolados de Alimentos A Antibióticos de Uso Farmacêutico. In: Anais do 12 Congresso Latinoamericano de Microbiologia e Higiene de Alimentos - MICROAL 2014 [= Blucher Food Science Proceedings, num.1, vol.1]. São Paulo: Editora Blucher, 2014. 
resistência de $100 \%$ das cepas a ampicilina e penicilina G. Com relação aos antimicrobianos Amicacina, Cefalexina, Gentamicina e Oxacilina houve resistência em $8 \%, 8 \%, 13 \%$ e $87 \%$ das cepas, respectivamente. A elevada incidência de Staphylococcus spp.resistentes aos antimicrobianos testados é preocupante, pois trata-se de bactérias de origem alimentar. A resistência bacteriana é considerada como um problema inerente à terapia antimicrobiana, por este motivo é preciso sempre buscar novas fontes terapêuticas os quais sejam mais eficientes para o tratamento de infecções.

Palavras-Chave: Antimicrobianos, Infecções, Resistência Agência de Fomento: CAPES 